\title{
GAMBARAN KADAR GLUKOSA DARAH PUASA MAHASISWA FAKULTAS KEDOKTERAN UNIVERSITAS SAM RATULANGI ANGKATAN 2011 DENGAN INDEKS MASSA TUBUH $\geq 23 \mathrm{~kg} / \mathrm{m}^{2}$
}

\author{
${ }^{1}$ Gracia Rorong \\ ${ }^{2}$ Stefana Kaligis \\ ${ }^{2}$ Diana Purwanto
}

\author{
${ }^{1}$ Kandidat Skripsi Fakultas Kedokteran Universitas Sam Ratulangi Manado \\ ${ }^{2}$ Bagian Biokimia Fakultas Kedokteran Universitas Sam Ratulangi Manado \\ Email: cy1510@ymail.com
}

\begin{abstract}
Glucose is a main compound that has important role in preparation and development of energy in human body. Blood glucose level is the amount of glucose in the blood. One of the factors that affects blood glucose level is body weight. Body weight is affected by several factors, such as aged, gender, and physical activities. Overweight may cause insulin resistance, results in increasing of the blood glucose level. This study aimed to describe the fasting blood glucose level at students Faculty of Medicine year 2011 Sam Ratulangi University with Body Mass Index $(\mathrm{BMI}) \geq 23 \mathrm{~kg} / \mathrm{m}^{2}$. Research method used for this study was cross sectional descriptive survey with purposive sampling method. From 26 respondents, 12 overweight (BMI $\geq 23 \mathrm{~kg} / \mathrm{m}^{2}$ ) respondents (46,15\%) had average fasting blood glucose level 85,4 mg/dL and 14 obese (BM2 $25 \mathrm{~kg} / \mathrm{m}^{2}$ ) respondents (53,85\%) had average fasting blood glucose level $86 \mathrm{mg} / \mathrm{dL}$. Conclusion: the description of fasting blood glucose level at students Faculty of Medicine year 2011 Sam Ratulangi University with Body Mass Index (BMI) $\geq 23 \mathrm{~kg} / \mathrm{m}^{2}$ is at normal level ( $80-100 \mathrm{mg} / \mathrm{dL}$ ).
\end{abstract}

Keywords: BMI $\geq 23 \mathrm{~kg} / \mathrm{m}^{2}$, Fasting blood glucose, students year 2011

\begin{abstract}
Abstrak: Glukosa merupakan suatu molekul utama yang berperan penting dalam penyediaan dan pembentukan energi di dalam tubuh. Kadar glukosa darah adalah jumlah kandungan glukosa dalam darah. Salah satu faktor yang mempengaruhi kadar glukosa darah adalah berat badan. Berat badan dipengaruhi oleh beberapa faktor, antara lain usia, jenis kelamin, dan aktivitas fisik. Kelebihan berat badan dapat menyebabkan resistensi insulin sehingga kadar glukosa dalam darah meningkat. Peningkatan kadar glukosa darah merupakan salah satu penanda sindroma metabolik. Penelitian ini bertujuan untuk mengetahui gambaran kadar glukosa darah puasa pada mahasiswa Fakultas Kedokteran Universitas Sam Ratulangi Angkatan 2011 dengan Indeks Massa Tubuh (I\#23) kg/m ${ }^{2}$. Jenis penelitian berupa penelitian survey deskriptif cross sectional dengan metode purposive sampling. Sampel penelitian sebanyak 26 orang responden. Hasil penelitian ini didapatkan 12 orang responden $(46,15 \%)$ yang overweight (IMT $\geq 23 \mathrm{~kg} / \mathrm{m}^{2}$ ) memiliki rata-rata kadar glukosa darah puasa $85,4 \mathrm{mg} / \mathrm{dL}$ dan 14 orang responden (53,85\%) yang obesitas (IMß25 kg/m ${ }^{2}$ ) memilki ratarata kadar glukosa darah puasa $86 \mathrm{mg} / \mathrm{dL}$. Simpulan: semua responden mahasiswa Fakultas Kedokteran Universitas Sam Ratulangi Angkatan 2011 memiliki kadar glukosa darah puasa normal (80-100 mg/dL).
\end{abstract}

Kata Kunci: Glukosa darah puasa, IMT $\geq 23$ kg/m², mahasiswa angkatan 2011 
Pada saat ini, obesitas telah menjadi masalah kesehatan dan gizi masyarakat dunia, baik di negara maju maupun di negara berkembang. Secara keseluruhan, ada perbedaan antara negara maju dan negara berkembang. Menurut review yang dilakukan oleh Low, dkk tahun 2009 bahwa prevalensi kelebihan berat badan (overweight) untuk pria dan wanita di negara maju berkisar dari 23,2\% di Jepang sampai 66,3\% di Amerika Serikat. Di negara berkembang berkisar $13,4 \%$ di Indonesia sampai 72,5\% di Arab Saudi. Prevalensi obesitas untuk pria dan wanita di negara maju berkisar dari 2,4\% di Republik Korea sampai 32,2\% di Amerika Serikat. Di negara berkembang berkisar 2,4\% di Indonesia sampai 35,6\% di Arab Saudi. ${ }^{1}$

Di Indonesia, Riset Kesehatan Dasar (Riskesdas) pada tahun 2007 menunjukkan bahwa 8,8\% orang dewasa berumur $>15$ tahun kelebihan berat badan dan 10,3\% obesitas. $^{2}$ Berdasarkan data Riskesdas tahun 2010, di Sulawesi Utara terdapat 13,7\% kelebihan berat badan dan 14,3\% obesitas pada laki-laki, sedangkan pada perempuan terdapat 16,8\% kelebihan berat badan dan 29,5\% obesitas. ${ }^{3}$ Berat badan yang meningkat menyebabkan insulin bekerja makin berat sehingga insulin tidak sanggup lagi mengubah semua glukosa menjadi sumber energi. Pada obesitas terjadi pelepasan asam lemak bebas ke dalam sirkulasi secara berlebihan. Asam lemak bebas berasal dari lipolisis triasilgliserol (TAG) jaringan adiposa. Makin banyak jaringan adiposa maka asam lemak bebas yang dilepaskan makin meningkat. Walaupun kadar insulin juga meningkat, tetapi pelepasan asam lemak bebas tetap terjadi. Sirkulasi asam lemak bebas semakin tinggi sehingga menghambat pengambilan glukosa oleh jaringan, glukosa yang berlebihan ini menetap dalam darah sehingga kadar glukosa dalam darah meningkat (hiperglikemia). ${ }^{4,5}$ Berdasarkan data Riset Kesehatan Dasar (Riskesdas) tahun 2007 mengenai hasil pengukuran kadar glukosa darah pada penduduk di Indonesia yang berumur >15 tahun, ditemukan prevalensi toleransi kadar glukosa darah terganggu adalah $10,2 \%$ dan prevalensi toleransi kadar glukosa darah terganggu di Sulawesi Utara sebesar 17,3\%. ${ }^{2}$ Penelitian ini bertujuan untuk mengetahui gambaran kadar glukosa darah puasa pada mahasiswa Fakultas Kedokteran Universitas Sam Ratulangi Angkatan 2011 dengan $\mathrm{IMT} \geq 23 \mathrm{~kg} / \mathrm{m}^{2}$.

\section{METODE PENELITIAN}

Penelitian ini merupakan penelitian survei deskriptif dengan rancangan Cross Sectional Study. Sampel penelitian berjumlah 26 orang responden berdasarkan metode pengambilan sampel Purposive Sampling, yaitu memilih sampel yang memenuhi kriteria tertentu: mahasiswa Fakultas Kedokteran Unsrat Angkatan 2011, IMT $\geq 23 \mathrm{~kg} / \mathrm{m}^{2}$, usia minimal 18 tahun, dan bersedia menjadi responden.

Pengambilan sampel dilakukan dengan menggunakan kuesioner untuk mendapatkan sampel yang sesuai dengan kriteria, kemudian dilakukan pengukuran berat badan dan tinggi badan, setelah itu sampel diminta untuk mengisi dan menandatangani informed consent.

Pengukuran Indeks Massa Tubuh (IMT) menggunakan rumus berat badan dalam kilogram $(\mathrm{kg})$ dibagi tinggi dalam meter kuadrat $\left(\mathrm{m}^{2}\right)$ dan penilaian kadar glukosa darah puasa dilakukan dengan pengambilan darah pada vena mediana cubiti setelah sampel berpuasa selama 1012 jam. Dalam penelitian ini klasifikasi Indeks Massa Tubuh (IMT) menggunakan kriteria World Health Organization (WHO) untuk Asia-Pasifik ${ }^{6}$ dan penilaian kadar glukosa darah puasa menggunakan kriteria menurut Perkeni tahun 2006.

\section{HASIL PENELITIAN}

Hasil penelitian menunjukkan dari 26 orang responden diperoleh data 12 orang (46,15\%) masuk dalam kategori Overweight, yaitu 9 orang laki-laki dan 3 orang perempuan, 14 orang lainnya (53,85\%) masuk dalam kategori Obesitas tingkat I dan Obesitas tingkat II, yaitu 6 
orang laki-laki dan 8 orang perempuan (Tabel 1).

Tabel 1. Distribusi Responden Berdasarkan Indeks Massa Tubuh (IMT)

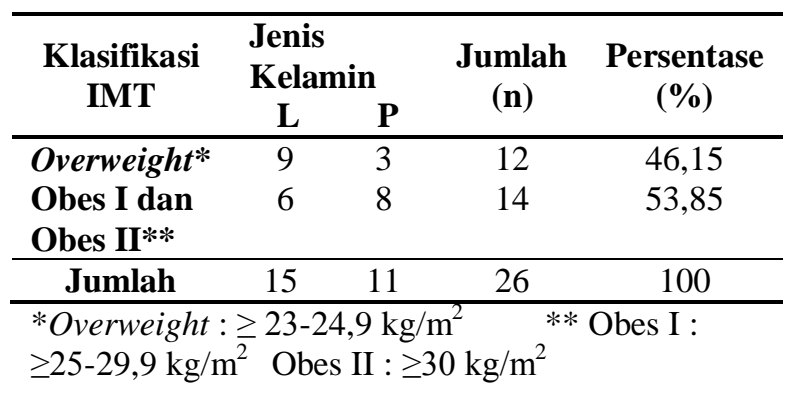

Tabel 2. Distribusi Responden Berdasarkan Kadar Glukosa Darah Puasa (GDP) Menurut Indeks Massa Tubuh (IMT)

\begin{tabular}{lccc}
\hline $\begin{array}{c}\text { Kadar } \\
\text { Glukosa } \\
\text { Darah } \\
\text { Puasa }\end{array}$ & \multicolumn{2}{c}{ Indeks Massa Tubuh } \\
Overweight* & $\begin{array}{c}\text { Obes I dan } \\
\text { Obes II** }\end{array}$ & $\begin{array}{c}\text { Jumlah } \\
\text { (n) }\end{array}$ \\
\hline $\begin{array}{l}\text { Normal } \\
\text { Tinggi }\end{array}$ & 12 & 14 & 26 \\
\hline$*$ Overweight $: \geq 23-24,9 \mathrm{~kg} / \mathrm{m}^{2}$ & $* *$ Obes I : \\
$\geq 25-29,9 \mathrm{~kg} / \mathrm{m}^{2}$ & Obes II $: \geq 30 \mathrm{~kg} / \mathrm{m}^{2}$ &
\end{tabular}

Tabel 3. Rata-rata Kadar Glukosa Darah Puasa (GDP) Berdasarkan Klasifikasi Indeks Massa Tubuh (IMT)

\begin{tabular}{lccc}
\hline \multicolumn{1}{c}{ IMT } & $\begin{array}{c}\text { Jumlah } \\
\text { (n) }\end{array}$ & $\begin{array}{c}\text { Persentase } \\
\text { (\%) }\end{array}$ & $\begin{array}{c}\text { Kadar } \\
\text { GDP } \\
\text { rata-rata } \\
\text { (mg/dL) }\end{array}$ \\
\hline $\begin{array}{l}\text { Overweight } \\
(\geq 23-24,9 \\
\left.\mathrm{g} / \mathrm{m}^{2}\right)\end{array}$ & 12 & 46,15 & 85,4 \\
$\begin{array}{l}\text { Obesitas }(\geq \\
\left.25 \mathrm{~kg} / \mathrm{m}^{2}\right)\end{array}$ & 14 & 53,85 & 86 \\
\hline
\end{tabular}

Berdasarkan hasil analisis laboratorium kadar glukosa darah puasa pada Mahasiswa Fakultas Kedokteran Unsrat Angkatan 2011 sebanyak 26 orang responden ini yang terdiri dari 12 orang $(46,15 \%)$ overweight dan 14 orang (53,85\%) obesitas didapatkan kadar glukosa darah puasa normal (Tabel 2).

Responden yang masuk dalam kategori overweight berjumlah 12 orang dengan rata-rata kadar glukosa darah puasa $85,4 \mathrm{mg} / \mathrm{dL}$, sedangkan responden yang masuk dalam kategori obesitas, baik obesitas I maupun obesitas II berjumlah 14 orang dengan rata-rata kadar glukosa darah puasa 86 mg/dL (Tabel 3).

\section{BAHASAN}

Peneliti mengambil 26 responden dari golongan umur 18-20 tahun dengan Indeks Massa Tubuh $\geq 23 \mathrm{~kg} / \mathrm{m}^{2}$. Menurut laporan New South Wales (NSW) Ministry of Health bahwa angka obesitas meningkat pada usia dewasa muda, Meagher pada tahun 2008 menyatakan adanya lonjakan obesitas di kalangan wanita usia dewasa muda. Dalam kurun waktu 10 tahun terjadi peningkatan dari $2,7 \%$ menjadi $9,9 \%{ }^{8}$

Dari 26 orang responden ini terdapat 12 orang $(46,15 \%)$ masuk dalam kategori overweight dan 14 orang (53,85\%) masuk dalam kategori obesitas. Dari 14 orang yang mengalami obesitas, terdapat 8 orang perempuan dan 6 orang laki-laki (Tabel 1). Beberapa penelitian menyimpulkan bahwa terdapat hubungan antara jenis kelamin dengan obesitas. Penelitian yang dilakukan oleh Sandjaja pada tahun 2005 menunjukkan bahwa prevalensi obesitas pada perempuan lebih tinggi daripada laki-laki. Penelitian yang dilakukan dengan analisis data sekunder Survei Kesehatan Rumah Tangga (SKRT) pada 10.000 rumah tangga di seluruh provinsi di Indonesia yang terdiri dari 20.137 responden ditemukan prevalensi obesitas pada perempuan sebesar 13,3\% dan pada laki-laki sebesar 5,3\%. ${ }^{9}$ Hal yang sama juga dilaporkan oleh Leksono di tahun 2008 melalui hasil survey Indeks Massa Tubuh (IMT) bahwa obesitas lebih dominan terjadi pada perempuan daripada laki-laki. Prevalensi obesitas pada perempuan sebesar $10,7 \%$ sedangkan pada laki-laki sebesar 5,5\%. ${ }^{10}$ Menurut laporan WHO pada penelitian Sandjaja tahun 2005 terdapat beberapa faktor yang berkaitan dengan tingginya prevalensi obesitas pada perempuan, antara lain konsumsi makanan berlemak yang lebih sering dan aktivitas 
olahraga yang jarang dilakukan. ${ }^{9}$ Perempuan juga lebih sering mengkonsumsi makanan ringan di luar jadwal makan serta melakukan gerakan otot yang lebih rendah dibandingkan laki-laki. ${ }^{10}$

Pada penelitian ini ditemukan kadar glukosa darah puasa pada rentang umur 1820 tahun dengan Indeks Massa Tubuh $\geq 23$ $\mathrm{kg} / \mathrm{m}^{2}$ masih dalam batas normal (Tabel 2). Hal ini disebabkan karena pada usia muda metabolisme glukosa dan aktivits fisik masih berlangsung dengan baik, sejalan dengan hasil penelitian Scheen di tahun 2005 bahwa seiring bertambahnya usia terjadi perubahan dalam metabolisme glukosa. Perubahan dalam metabolisme glukosa pada usia tua ditunjukkan dengan adanya penurunan sensitivitas insulin pada jaringan target dan penurunan fungsi sel beta pankreas. ${ }^{11}$ Rochmah $\mathrm{W}$ berpendapat bahwa usia mempengaruhi kadar glukosa darah, setelah seseorang mencapai 30 tahun kadar glukosa darah puasa naik 1-2 mg\%/tahun. Hal ini terjadi karena jumlah massa otot berkurang, terjadi peningkatan jaringan lemak, dan penurunan aktivitas fisik yang mengakibatkan sensitivitas insulin menurun, ${ }^{2}$ tetapi beberapa hal tersebut tidak cukup kuat menjelaskan pengaruh usia terhadap peningkatan kadar glukosa darah. Dalam penelitiannya pada tahun 2011, Gunasekaran menemukan bahwa terjadi penurunan kapasitas dan proliferasi sel beta pankreas seiring bertambahnya usia. ${ }^{13}$ Seiring bertambahnya usia, terjadi pula penurunan dehidroepiandrosteron (DHEAS) plasma akibat kenaikan lemak tubuh dan penurunan aktivitas yang dapat mengakibatkan resistensi insulin. ${ }^{12}$

Penelitian yang dilaksanakan oleh Rizzo, dkk di tahun 2008 menyatakan bahwa aktivitas fisik berperan dalam mempertahankan keseimbangan metabolisme pada usia dewasa muda. ${ }^{14}$ Selama adanya aktivitas fisik, glukosa dan asam lemak dibutuhkan untuk bahan bakar metabolisme, maka glukagon akan meningkat sedangkan insulin menurun. Hormon insulin yang disekresi selama aktivitas fisik berlangsung diatur oleh berbagai faktor, antara lain konsentrasi glukosa darah dan kadar glukagon dalam plasma. ${ }^{15}$

Hasil penelitian ini menunjukan gambaran rata-rata kadar glukosa darah puasa pada responden yang masuk dalam kategori obesitas lebih tinggi dibandingkan dengan gambaran rata-rata kadar glukosa darah puasa responden yang overweight (Tabel 3). Hasil ini sejalan dengan penelitian Villalpando, dkk pada tahun 2007 yang menunjukkan ada hubungan antara obesitas dan risiko peningkatan kadar glukosa darah, dimana rata-rata konsentrasi glukosa secara signifikan lebih tinggi pada obesitas dibandingkan dengan berat badan normal $(\mathrm{p}<0,05) .{ }^{16}$ Penelitian menunjukkan bahwa overweight dan obesitas pada usia muda merupakan faktor resiko terjadinya sindroma metabolik pada usia dewasa. ${ }^{17}$ Data penelitian ini menunjukkan bahwa sudah ada risiko terjadinya sindroma metabolik di usia dewasa pada Mahasiswa Fakultas Kedokteran Unsrat Angkatan 2011 terutama pada responden yang mengalami obesitas.

\section{SIMPULAN}

Dari penelitian ini dapat disimpulkan bahwa semua responden mahasiswa Fakultas Kedokteran Universitas Sam Ratulangi Angkatan 2011 memiliki kadar glukosa darah puasa normal (80-100 $\mathrm{mg} / \mathrm{dL}$ ).

\section{UCAPAN TERIMA KASIH}

Ucapan terima kasih disampaikan pada: Mahasiswa Fakultas Kedokteran Universitas Sam Ratulangi Angkatan 2011 yang telah bersedia menjadi sampel penelitian, Laboratorium ProKita yang telah membantu pemeriksaan Laboratorium pada penelitian ini, dr. Murniati Tiho, MKes, dr. Yanti Mewo, MPdKed, dan pada semua pihak yang baik secara langsung maupun tidak langsung telah menumbuhkan ide atau gagasan dalam pemikiran penulis sehingga dapat menyelesaikan artikel ini. 


\section{DAFTAR PUSTAKA}

1. Low S, Chin MC, Deurenberg-Yap M. Review on epidemic of obesity. Ann Acad Med Singapore, 2009;38:57-65.

2. Badan Penelitian dan Pengembangan Kesehatan Depkes RI. Riset kesehatan dasar 2007. Jakarta: Balitbangkes Depkes RI, 2008.

3. Badan Penelitian dan Pengembangan Kesehatan Depkes RI. Riset kesehatan dasar 2010. Jakarta: Balitbangkes Depkes RI, 2010.

4. Guyton AC, Hall JE. Buku Ajar Fisiologi Kedokteran. Edisi 11. Rachman LY, Hartanto H, Novrianti A, Wulandari N, alih bahasa. Jakarta: EGC, 2007.p.1010-27.

5. Cahjono H, Budhiarta AAG. Hubungan resistensi insulin dengan kadar nitrit oksida pada obesitas abdominal. J Peny Dalam, 2007;8.p.23-36.

6. Inoue $\mathbf{S}$, Zimmet $\mathbf{P}$. The asia-pacific perspective: redefining obesity and its treatment. Health Communications Australia, 2000.

7. Perkeni 2006. Konsensus Pengelolaan Dan Pencegahan Diabetes Mellitus Tipe 2 Di Indonesia 2006. Perkeni. Jakarta.

8. Meagher R. Report shows obesity rates are increasing amongst young adults. NSW government health, 2008. Available from: www.health.nsw.gov.au/news. Accessed on: 15 Januari 2013.

9. Sandjaja, Sudikno. Prevalensi gizi lebih dan obesitas penduduk dewasa di Indonesia. Gizi Indon, 2005;31.

10. Leksono P. Survey indeks massa tubuh (IMT) di kota Kendari provinsi Sulawesi Tenggara. SELAMI IPS, 2008;1.
11. Scheen AJ. Diabetes mellitus in elderly: insulin resistance and/or impaired insulin secretion. Diabetes and Metabolism, 2005;31.

12. Rochmah W. Diabetes melitus pada usia lanjut. Dalam: Sudoyo AW, Setiyohadi B, Alwi I, Simadibrata KM, Setiati S, penyunting. Buku Ajar Ilmu Penyakit Dalam. Jilid III. Edisi 5. Jakarta: Balai Penerbit FKUI, 2009.p.1967-9.

13. Gunasekaran U, Gannon M. Type 2 diabetes and the aging pancreatic beta cell. Open Access Impact Journal on Aging, 2011;3.

14. Rizzo NS, Ruiz JR, Oja L, Veidebaum T, Sjöström M. Associations between physical activity, body fat, and insulin resistance (homeostasis model assessment) in adolescents: the european youth heart study. Am J Clin Nutr 2008;87:586 -92.

15. Bawono MN. Kontrol hormon insulin dan glukagon dalam perubahan metabolisme selama latihan. Jurnal Pelangi Ilmu Universitas Negeri Surabaya, 2008:2;2.

16. Villalpando S, Carrion C, Barquera S, Fernandez GO, Robledo R. Body mass index associated with hyperglycemia and alterations of components of metabolic syndrome in Mexican adolescents. Salud Publica Mex, 2007;49:suppl 3.

17. Vanhala MJ, Vanhala PT, KeinanenKiukaanniemi SM, Kumpusalo EA, Takala JK. Relative weight gain and obesity as a child predicts metabolic syndrome as an adult. Int $\mathrm{J}$ Obes 1999;23:656-9. 